УДК 35.071 .1

DOI https://doi.org/10.32838/2707-0581/2020.1/24

\title{
Кравченко Н.М.
}

Київський факультет

Національної академії Національної гвардії України

\section{АНАЛІЗ ТЕОРЕТИЧНИХ ПОЛОЖЕНЬ ПСИХОЛОГІЧНОГО ЗАБЕЗПЕЧЕННЯ СЛУЖБОВО-БОЙОВОї ДІЯЛЬНОСТІ}

У науковій статті розкрито роль психологічного забезпечення службово-бойової діяльності сил охорони правопорядку. Зроблено аналіз основних теоретичних положень психологічного забезпечення в умовах як службово-бойової, так і повсякденної діяльності. На прикладі нормативно-правових документів розкрито основні найбільш уживані терміни, категорії й теоретичні положення психологічного забезпечення службово-бойової діяльності. Виокремлено проблемні питання, на розв'язання яких необхідно звернути увагу в наукових дослідженнях з метою нормативного закріплення та подальшої практичної реалізачії. Запропоновано шляхи й способи розв'язання пріоритетних завдань, які є актуальними із ицього напряму.

Для досягнення мети й вирімення пріоритетних завдань запропоновано виконання комплексних заходів. Насамперед варто звернути увагу на вдосконалення нормативно-правової бази; прискорене впровадження системи психологічної підготовки; рівень підготовки офіцерського, стариинського та сержантського складу з питань роботи з підлеглим особовим складом; моральне вдосконалення матеріально-технічної бази, технологій, форм і методів організачії та проведення психологічного забезпечення; стан фінансування для подальшого всебічного розвитку иьього напряму.

Дійшли висновку, що необхідно вжити заходи щодо вдосконалення теоретичних положень системи психологічного забезпечення, яка включає в себе комплекс організаційних, методичних, просвітницьких, психопрофілактичних, психодіагностичних, психоформувальних і психокорекиійних заходів, спрямованих на вивчення, формування та розвиток в особового складу професійно важливих психічних якостей, підтримання й відновлення оптимальних психічних станів, необхідних для успішного виконання службово-бойових завдань, збереження високого рівня психологічної безпеки та психологічного стану, запобігання виникненню професійної деформації. Усе ие буде запорукою збереження фізичного та психічного здоров'я, підвищення психологічної стійкості, надійності й готовності сил охорони правопорядку до виконання завдань за призначенням.

Ключові слова: психологічне забезпечення, службово-бойова діяльність, сили охорони правопорядку, морально-психологічний стан, психологічна підготовка, психологічна допомога.

Постановка проблеми. Наша держава невпинно рухається вперед шляхом реформ, переборюючи застарілі стереотипи й погляди щодо стилю та методів управління країною й суспільством. Цей процес стосується всіх силових структур, у тому числі й сил охорони правопорядку. Відбувається пошук ефективних засобів, форм і методів впливу на особовий склад $з$ метою ефективного виконання завдань підтримання внутрішньої безпеки держави.

У наш час зміщуються акценти в роботі командирів і начальників усіх рівнів з командно-адміністративних на психолого-педагогічні методи впливу на підлеглих. Такі тенденції зумовлені не лише наслідуванням загальносвітового процесу психологізації всіх сфер життя сучасного соціуму, а й наявним потенціалом психологічного забезпечення службово-бойової діяльності сил охорони правопорядку, прикладне використання якого може зумовити якісно новий рівень їх функціонування $[1$, с. 6].

У цьому сенсі варто згадати дуже влучний вислів відомого військового та державного діяча M.I. Драгомирова: «Досконале озброєння, якісний план, знання військами техніки означають дуже багато, але не більш як нулі, коли зліва від них стоїть одиниця... Цією одиницею у воєнній справі, як і у будь-якому виді діяльності, $\epsilon$ людина». Цей вислів переконливо свідчить про важливу роль психологічної підготовки, а також подальшого психологічного забезпечення в силових структурах.

Формування та підтримання відповідного духовного стану суспільства й морально-психологічного стану особового складу військ (сил) 
як у мирний час, так і в період воєнного протиборства неможливі без наявності в населення країни, його соціальних груп, збройних сил, військових колективів, конкретної особистості духовного (морально-психологічного) потенціалу. Саме тому морально-психологічний фактор у сучасній війні (збройному конфлікті) набуває особливого значення, стає одним із головних для держави та іiі збройних сил [2, с. 8].

Аналіз останніх досліджень і публікацій. Вагомий внесок у розроблення теоретичних основ проведення психологічної роботи у військах та органах внутрішніх справ України зробили такі фахівці у сфері військової психології, як Д.О. Александров, В.Г. Андросюк, Л.М. Балабанова, В.І. Барко, М.Й. Варій, Ю.Б. Ірхін, В.М. Корольчук, М.С. Корольчук, В.О. Лефтеров, I.I. Ліпатов, О.А. Матеюк, В.С. Медведєв, О.М. Морозов, В.І. Осьодло, С.М. Потапчук, I.I. Приходько, О.Д. Сафін, В.В. Стасюк, О.В. Тімченко, В.В. Ягупов, С.І. Яковенко, В.М. Крайнюк, О.Ф. Хміляр і багато інших.

Разом із тим, незважаючи на те що питання психологічного забезпечення тим чи іншим чином розглядалися як вітчизняними, так і зарубіжними науковцями, багато аспектів цього напряму є ще мало досліджуваними й потребують більшої уваги.

Постановка завдання. Мета статті полягає в тому, щоб на підставі наявних наукових і нормативних джерел зробити аналіз теоретичних положень психологічного забезпечення службовобойової діяльності сил охорони правопорядку та запропонувати комплекс заходів спрямованих на їх удосконалення.

Виклад основного матеріалу дослідження. У військовій сфері та у сфері інших силових структур діяльність психолога має свої особливості. Зміст та особливості сучасної війни, іiї технічна й морально-психологічна насиченість передбачають високу громадянську свідомість, справжню бойову майстерність, психологічну стійкість і готовність воїнів переносити проблеми сучасної війни. Ці якості грунтуються на базі гуманітарної, тактичної, спеціальної, технічної, вогневої, фізичної та загальновійськової підготовки військовослужбовців [3].

Варто зазначити, що психологічне забезпечення в правоохоронних органах і військових формуваннях характеризується введенням штатних посад психологів, а також створенням психотренінгових центрів і позаштатних пунктів психологічної допомоги й реабілітації, вдоскона- ленням діяльності науково-дослідних підрозділів, що досліджують проблеми найбільш ефективного застосування потенціалу психології в умовах як службово-бойової, так і повсякденної діяльності.

До сил охорони правопорядку зараховують Національну гвардію України, Службу безпеки України, Національну поліцію України, Державну прикордонну службу України, Державну службу України 3 надзвичайних ситуацій, Державну міграційну службу України, Військову службу правопорядку Збройних Сил України та Управління державної охорони України. Але на рівні нормативних документів психологічному забезпеченню основну увагу приділено лише Національній гвардії Україні та Державній службі України 3 надзвичайних ситуацій.

На основі Наказу МВС України «Про затвердження Положення про психологічне забезпечення в Національній гвардії України» від 08.12.2016 № 1285 розглянемо основні теоретичні положення психологічного забезпечення службово-бойової діяльності.

Терміни, що закріплені у вищезазначеному розпорядчому документі, мають такі значення:

- декомпресія - форма психологічної реабілітації військовослужбовців, які перебували в екстремальних (бойових) умовах службово-бойової діяльності, яка складається з комплексу заходів фізичного та психологічного відновлення організму людини та проводиться з метою поступової реадаптації військовослужбовців до звичайних умов життєдіяльності, запобігання розвитку в них психологічних травм;

- екстремальні (бойові) умови - умови службово-бойової діяльності особового складу, що знижують психологічну безпеку, загрожують життю і здоров'ю людей і спричиняють вплив стрес-факторів (безпосередня загроза для життя, поранення, застосування зброї на ураження, присутність під час загибелі людей, робота із залишками тіл, перебування в заручниках чи полоні, фізичне, психологічне та сексуальне насильство), унаслідок чого підвищується тривожність, емоційна напруженість, створюється психотравмувальний вплив на психіку людини;

- поліграф - різновид психофізіологічної апаратури, що використовує комплексну багатоканальну комп'ютерну методику реєстрації змін психофізіологічних реакцій людини на певні психологічні стимули;

- посилена психологічна увага - система комплексних заходів психологічного характеру, що здійснюються 3 визначеною групою осіб, які 
потребують першочергової психологічної допомоги у зв'язку з особливостями впливу на них стресогенних факторів службової й позаслужбової діяльності та навчально-виховного процесу, 3 метою своєчасної профілактики надзвичайних подій і запобігання їм серед особового складу, підвищення рівня його адаптаційних можливостей до умов службово-бойової діяльності й забезпечення психологічного благополуччя, збереження психічного та фізичного здоров'я, запобігання службовому та побутовому травматизму;

- професійно-психологічний відбір - безперервний керований процес, що включає комплекс психодіагностичних заходів щодо виявлення рівня розвитку професійно важливих якостей особистості й визначення рівня придатності кандидатів для проходження військової служби за контрактом і служби у військовому резерві, участі в міжнародних операціях з підтримання миру й безпеки в складі національного персоналу або національного контингенту, навчання у вищих військових навчальних закладах (навчальних військових частинах (центрах), призначення кандидатів на керівні посади, а також прогнозування подальшої службово-бойової діяльності військовослужбовців за обраною військовою спеціальністю;

- психологічна допомога - вид допомоги, що надається людині чи групі людей для відновлення необхідної якості психологічних станів, покращення функціонування психічних процесів, поведінки, спілкування та їх реалізації в груповій діяльності;

- психологічна експрес-діагностика - швидке оцінювання індивідуально-психологічних особливостей військовослужбовців 3 метою встановлення ступеня їх відповідності вимогам та умовам виконання службових обов'язків, контроль за психоемоційним станом військовослужбовців і визначення необхідності в наданні відповідної психологічної підтримки, допомоги;

- психологічна підтримка - система соціально-психологічних, психолого-педагогічних засобів, способів і методів допомоги особі з метою оптимізації іiї психоемоційного стану в процесі формування здібностей і самосвідомості, спрямування зусиль особи на реалізацію власної професійної діяльності;

- психологічна просвіта - систематичне та організоване розповсюдження серед особового складу психологічної інформації з метою формування в нього розуміння закономірностей функціонування людської психіки й поведінки людей в екстремальних умовах, формування знання шляхів і способів управління можливостями власної психіки, надання самодопомоги та першої психологічної допомоги іншим військовослужбовцям, а також готовності й бажання отримувати професійну психологічну допомогу в разі потреби;

- психологічна реабілітація - система заходів, спрямованих на збереження, відновлення та корекцію психологічних станів, необхідних для забезпечення оптимального рівня боєздатності військовослужбовців, які були піддані впливу психотравмувальних стрес-факторів, а також створення сприятливих умов для подальшого успішного виконання ними службово-бойових завдань;

- психологічне інформування (інструктаж) форма проведення професійно-психологічної підготовки особового складу перед виконанням службово-бойового завдання, що передбачає формування командирами (начальниками) у військовослужбовця образу майбутніх дій і можливих надзвичайних ситуацій; створення необхідної психологічної установки, готовності, емоційного настрою на ефективне виконання службово-бойових завдань; зняття надлишкової психологічної напруги;

- психологічне консультування - комплекс заходів, які застосовуються (за необхідності) для надання військовослужбовцям психологічної інформації, емоційної підтримки й уваги до їхніх переживань, що допомагають прийняти усвідомлене рішення та оцінити психологічні ресурси щодо бажаних поведінкових змін, допомоги, спрямованої на усвідомлення впливу стрес-факторів, розширення самосвідомості й підвищення психологічної компетентності, зміну ставлення до проблеми, підвищення стресової та кризової толерантності, відповідальності, засвоєння нових моделей поведінки;

- психологічне моделювання - форма проведення професійно-психологічної підготовки особового складу, яка полягає в наданні керівниками занять увідних даних щодо створення реалістичного образу, тактики дій, бойових можливостей імовірного противника чи правопорушників, створення фізичних і психічних навантажень, характерних для виконання службово-бойових завдань;

- психологічний супровід виконання службово-бойових завдань - комплекс заходів 3 підтримання оптимального стану психологічного здоров'я військовослужбовців під час виконання ними службово-бойових завдань шляхом формування їх психологічної стійкості до впливу стресових чинників, психологічної готовності 
до виконання завдань служби за призначенням i запобігання виникненню негативних психологічних станів;

- психопрофілактика - комплекс організаційних, службових, правових, просвітницьких, соціально-економічних, психологічних i медичних заходів, спрямованих на запобігання виникненню та розвитку психічних розладів, негативних психологічних станів за допомогою створення сприятливих психологічних умов для навчання, виконання службово-бойових завдань, запобігання психологічному виснаженню, зниження рівня психологічної безпеки особистості, професійного вигорання та деформації особового складу, надання психологічної підтримки військовослужбовцям, особливо в період їх адаптації до військової служби, і військовослужбовцям, зарахованим до групи посиленої психологічної уваги, з метою забезпечення їх високої працездатності й ефективності службово-бойової діяльності;

- соціально-психологічний клімат військового колективу - сукупність характеристик стану групової психіки, ставлення військовослужбовців до умов і характеру службово-бойової діяльності підрозділу, колег по службі, командирів (начальників) [4].

Разом із тим терміни, які ми розглянули вище, мають не вичерпний перелік. Саме тому, на нашу думку, доцільно буде розглянути Наказ МВС України «Про затвердження Порядку психологічного забезпечення в Державній службі України 3 надзвичайних ситуацій» від 31.08.2017 № 747, на основі якого розкрити ті теоретичні положення, які не згадувалися в попередньому Наказі, але які мають вагоме значення в психологічному забезпеченні Державної служби України з надзвичайних ситуацій.

Ці терміни вживаються в таких значеннях:

- екстрена психологічна допомога - це система короткострокових заходів, націлених на регуляцію актуального психологічного, психофізіологічного стану та негативних переживань людини або групи людей, постраждалих унаслідок надзвичайної ситуації, за допомогою професійних методів, які відповідають вимогам ситуації;

- психологічна підготовка - комплекс взаємопов'язаних заходів, які здійснюються в загальній системі службової підготовки, а також у навчальновиховному процесі та безпосередньо в процесі виконання завдань за призначенням, які спрямовані на формування, розвиток і підтримку психологічної готовності осіб рядового й начальницького складу служби цивільного захисту (далі - особи рядового й начальницького складу), рятувальників до професійної діяльності, виконання завдань за призначенням у складних та екстремальних умовах;

- психологічне відновлення - система заходів, спрямованих на збереження, відновлення та корекцію психічних станів, створення сприятливих умов, необхідних для забезпечення оптимального рівня готовності до виконання завдань за призначенням;

- психологічне забезпечення - комплекс психодіагностичних, психопрофілактичних і психокорекційних заходів, спрямованих на вивчення, формування та розвиток в осіб рядового й начальницького складу, рятувальників і працівників професійно важливих психологічних якостей, підтримання позитивних психічних станів, необхідних для успішного виконання завдань за призначенням і збереження високого рівня психологічної безпеки;

- стрес-фактори - обставини, що викликають стресовий стан [5].

На основі аналізу вищезазначених нормативно-правових документів можна зробити висновок, що, незважаючи на нормативно-правові акти та наукові джерела, у яких тим чи іншим чином згадуються положення про психологічне забезпечення, наявність лише двох наказів із цього напряму говорить про недостатнє його вивчення та, як наслідок, прогалини в законодавстві із цього питання.

Отже, проблема організації надання психологічної допомоги та здійснення психокорекційної роботи у військових частинах, формування групи посиленої психологічної уваги й робота з військовослужбовцями, які до неї зараховані, є важливою та актуальною, водночас вона не достатньо широко розроблена в керівних документах i методичних матеріалах, які використовуються військовими психологами, іншими посадовими особами під час організації роботи 3 особовим складом [6, с. 5].

Для досягнення мети й вирішення пріоритетних завдань необхідно забезпечити виконання комплексних заходів і звернути увагу на таке:

- удосконалення нормативно-правової бази;

- прискорене впровадження системи психологічної підготовки;

- рівень підготовки офіцерського, старшинського та сержантського складу 3 питань роботи з підлеглим особовим складом;

- моральне вдосконалення матеріально-технічної бази, технологій, форм і методів організації та проведення психологічного забезпечення; 
- стан фінансування для подальшого всебічного розвитку цього напряму.

Виходячи з вищевикладеного, доцільно сформулювати такі рекомендації:

1) оцінити стан та ефективність психологічного забезпечення за сучасних умов;

2) під час розроблення нормативно-правових документів урахувати особливості функціонування психологічного забезпечення;

3) удосконалити організаційно-штатні структури органів, які безпосередньо відповідають за організацію психологічного забезпечення;

4) підвищити вимоги до загального рівня підготовки офіцерського складу з питань організації роботи з людьми; управління військовими колективами; володіння прийомами, формами, методами роботи з особовим складом;

5) спрямувати діяльність наукових установ на наукове й методичне вирішення проблем психологічної підготовки особового складу сил охорони правопорядку з метою їх якісного психологічного забезпечення;

6) оснащення військ (сил) сучасними технічними засобами психологічного забезпечення.

Висновки. Отже, в реаліях сьогодення відбувається пошук ефективних засобів, форм і методів впливу на особовий склад 3 метою ефективного виконання завдань підтримання внутрішньої безпеки держави.

Як результат, необхідно вжити заходи щодо вдосконалення теоретичних положень системи психологічного забезпечення, яка включає в себе комплекс організаційних, методичних, просвітницьких, психопрофілактичних, психодіагностичних, психоформувальних і психокорекційних заходів, спрямованих на вивчення, формування та розвиток в особового складу професійно важливих психічних якостей, підтримання й відновлення оптимальних психічних станів, необхідних для успішного виконання службовобойових завдань, збереження високого рівня психологічної безпеки та психологічного стану, запобігання виникненню професійної деформації. Усе це буде запорукою збереження фізичного та психічного здоров'я, підвищення психологічної стійкості, надійності й готовності сил охорони правопорядку до виконання завдань за призначенням.

Отже, підбиваючи підсумки, ми дійшли висновку, що теоретичні положення психологічного забезпечення службово-бойової діяльності потребують значного наукового дослідження, нормативного закріплення та подальшої практичної реалізації.

\section{Список літератури:}

1. Прикладна психологія службово-бойової діяльності сил охорони правопорядку : підручник / І.І. Приходько, І.І. Ліпатов, Л.Ф. Шестопалова та ін. ; за заг. ред. проф. І.І. Приходька, 2-ге вид. Харків : НА НГУ, 2016. 334 с.

2. Морально-психологічне забезпечення у Збройних Силах України : підручник : у 2 ч. / колектив авторів ; за заг. ред. В.В. Стасюка. Київ : НУОУ, 2012. Ч. 1. 682 с.

3. Ягупов В.В. Загальнодидактичні основи навчання військовослужбовців строкової служби Збройних сил України : автореф. дис. ... докт. пед. наук : 13.00.04. Київ, 2002. 34 с.

4. Про затвердження Положення про психологічне забезпечення в Національній гвардії України : Наказ МВС України від 08.12.2016 № 1285. Офічійний вісник України. 2017. № 13. С. 133. Ст. 379.

5. Про затвердження Порядку психологічного забезпечення в Державній службі України з надзвичайних ситуацій : Наказ МВС України від 31.08.2017 № 747. Офіиійний вісник Украӥни. 2017. № 96. С. 527. Ст. 2944.

6. Форми і методи надання психологічної допомоги та здійснення психокорекційної роботи у військових частинах, установах і закладах 3С України : навчально-методичний посібник / укл. О.М. Чепур, В.Д. Наконечний, В.Е. Петухов. Київ, 2013. 54 с.

\section{Kravchenko N.M. ANALYSIS OF THEORETICAL PROVISIONS \\ OF THE PSYCHOLOGICAL SUPPORT OF THE MILITARY-COMBAT ACTIVITY}

In the scientific article the role of psychological support of the military-combat activity of law enforcement forces is revealed. The analysis of the basic theoretical provisions of psychological support, both in terms of combat and daily activities. The most commonly used terms, categories and theoretical provisions of psychological support for combat service are revealed on the example of legal documents. The problematic issues that need to be addressed in scientific research for regulatory support and further practical implementation are highlighted. The ways and method of solving priorities tasks that are relevant in this area are suggested.

Complex measures are proposed to achieve the goal and address the priority tasks. First of all, we should pay attention to: improvement of the regulatory framework; accelerated implementation of the psychological 
training system; the level of training of officers, sergeants and sergeants on the work with subordinate personnel; moral improvement of material and technical base, technologies, forms and methods of organization and carrying out psychological support; state of financing for the further comprehensive development of this area.

It was concluded that it is necessary to take measures to improve the theoretical provisions of the psychological support system, which includes a set of organizational, methodological, educational, psychoprophylactic, psychodiagnostic, psycho-forming and psycho-corrective measures aimed at the study, formation and development in the professional staff and restoration of optimal mental states necessary for successful performance of combat tasks, maintaining a high level of psychological safety and psychological condition, prevention of professional deformation. All this will guarantee the preservation of physical and mental health, increase psychological stability, reliability and readiness of law enforcement forces to performing tasks on purpose.

Key words: psychological support, military-combat activity, forces of law enforcement, moral and psychological state, psychological preparation, psychological assistance. 